\title{
The Influence of Leadership 3.0 Implementation and Work Motivation On Employee Performance of Telkom Witel Banten
}

\author{
$1^{\text {st }}$ Jatmiko Reno R., $2^{\text {nd }}$ Ratri Wahyuningtyas. \\ \{renno95@gmail.com¹, Ratri19.telkomuniversit@gmail.com².\} \\ Telkom University, Bandung ${ }^{1}$, Telkom University, Bandung ${ }^{2}$.
}

\begin{abstract}
.
The concept of Leadership 3.0 is the art of horizontal leadership for everyone, the art of influencing others without relying on titles. Research aims to determine the effect of leadership style 3.0 and work motivation on employee performance at Telkom Witel Banten. The sampling technique used in this research is saturated sampling technique on nonprobability sampling. The total population of this study was 104 people, the sample to be used was 103 people, namely all employees of PT. Telkom Witel Banten except the General Manager of Witel Banten as a Leader. The analysis technique uses descriptive analysis, and data can be calculated using the SPSS application. The results of the study using multiple regression analysis show that the implementation of leadership 3.0 and work motivation simultaneously influences and can be explained to improve the performance of employees of PT Telkom Witel Banten.
\end{abstract}

Keywords: Leadership 3.0, performance, motivation

\section{Introduction}

In the era of information technology, many leadership styles have developed. Starting in leadership 1.0 with a leadership style that was inherited by Leadership 3.0 which was developing in the current industrial 4.0 era. The concept of Leadership 3.0 is the art of horizontal leadership for everyone, the art of influencing others without relying on titles and positions. With intense business competition, a leader is needed who is able to make people move, work and be productive without being forced. This needs to be supported by the company. Companies must pay attention to how to maintain and manage employee motivation at work so that it is always high and focused on company goals. People will not do something optimally if they do not have high motivation from within themselves to do it. Motivation can foster a sense of belonging, in the end it can increase participation and communication as well as foster empathy or the ability to put oneself in the position of others. 
In the current era of globalization, the level of competition faced by companies to seek profits and achieve company targets is seen getting higher every year. The target set by the Consumer Directorate also increases every year. To achieve the company's target, the company must improve the quality of the performance of its employees so as to provide satisfaction to customers. Table 1 shows targets and realization of Indigenous Telkom Witel Banten Indihome NAL customers during 2017-2019.

Table 1. Indihome NAL Target and Realization Data for 2017-2018.

\begin{tabular}{|c|c|c|c|}
\hline Year & Target & Realization & Persentase \\
\hline $\mathbf{2 0 1 7}$ & 30000 & 18978 & $63,26 \%$ \\
\hline $\mathbf{2 0 1 8}$ & 40000 & 29214 & $73,03 \%$ \\
\hline $\mathbf{2 0 1 9}$ & 41000 & 32338 & $78,87 \%$ \\
\hline
\end{tabular}

Leadership 3.0 is believed to be able to influence everyone because it is an art of leadership for anyone such as salesmen, entrepreneurs, private employees, civil servants, consultants, law enforcement, social activists, teachers, parents, and anyone who wants to spread influence and create change to humans and the surrounding environment, Ridwansyah [2].

Based on the background of the research described, the researchers conducted a study to examine leadership 3.0, and work motivation on the performance of Telkom Witel Banten employees.

\section{Basic Theory, Framework, and Methodology}

\subsection{Basic Theory}

\subsubsection{Employee Performance}

According to Mangkunegara [3], "Performance is the quality and quantity of work achieved by an employee in carrying out his job in accordance with the responsibilities assigned to him". Then Rivai and Moch. Basri [4] states that performance is an achievement achieved by a person in carrying out his duties or jobs in accordance with the standards and criteria set for the job. Meanwhile, according to Ambar Teguh Sulistiyani [5] "A person's achievement is a combination of abilities, efforts and opportunities that can be assessed from the results of his performance".

\subsubsection{Motivation}

Motivation comes from another word "Movere" which means "impulse or driving force" This motivation is only given to humans, especially to subordinates or followers [1] quoted in Danang Sunyoto [6]. 


\subsubsection{Leadership Style}

According to Rivai and Mulyadi [4] leadership style is the overall pattern of the actions of a leader, both visible and invisible. Leadership style describes a consistent combination of philosophy, skills, traits and attitudes that underlie a person's behavior.

\subsubsection{Leadership 3.0}

Stephen J. Samson in Ridwansyah [2] a psychologist and pioneer of Social Intelligence Skills, explained that there are six aspects that support the presence of a Leadership 3.0, namely aspects of physicality, intellectuality, emotionality, sociability, personability, and moralability. Some aspects of Leadership 3.0 are an update of the old leadership concept, and strongly reflect the way of leadership in the information technology era.

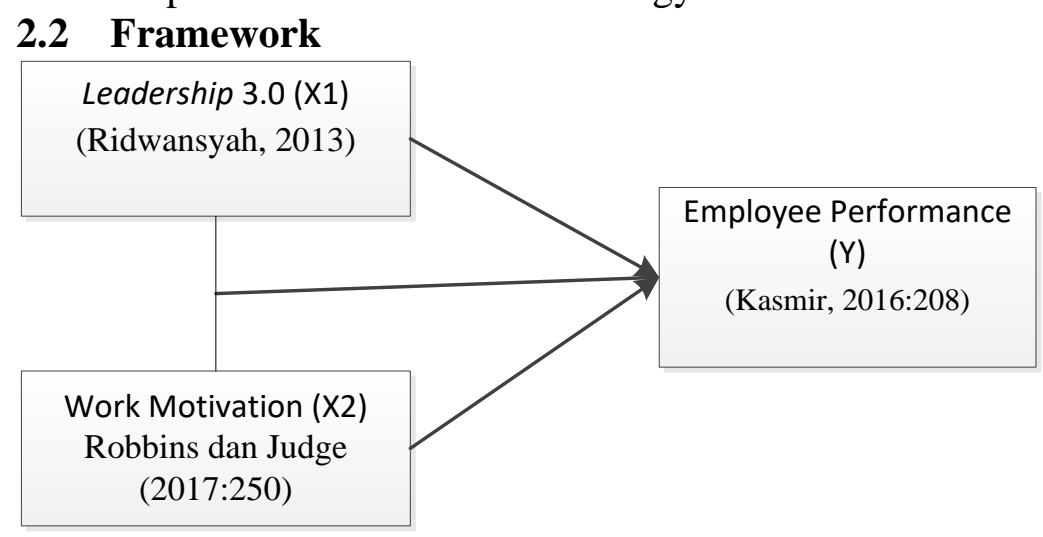

Fig 1. Framework

\subsection{Research Methodology}

This research was designed using descriptive methods with a quantitative approach. Descriptive statistical methods are used to explain the phenomena that occur regarding research data. Research collects data through questionnaires to employees whose results are then processed to determine the effect of Implementation of Leadership 3.0 (X1), Work Motivation (X2) with Employee Performance (Y) either partially or simultaneously.

\section{The Result of Research and Discussion}

\subsection{Descriptive Analysis and Discussion}

The percentage for the Leadership 3.0 (X1) variable is in the Good category. In other words, respondents argue that the implementation of Leadership 3.0 at Telkom Witel Banten is good enough but it is important to be further improved in terms of physical aspects and personality aspects. It can be 
seen that the highest percentage is found in sub-variables of social aspects, that is equal to $85.37 \%$ and the lowest value is found in sub-variables of physical aspects and personality aspects with a magnitude of $81.49 \%$.

Percentage for work motivation variable (X2) is in the Very Good category. In other words, the respondent believes that work motivation at PT. Telkom Witel Banten is already good but it is important to be further improved in terms of achievement needs for Telkom Witel Banten employees. It can be seen that the highest percentage is found in the power variable sub-variable, that is equal to $84.66 \%$ and the lowest value is in the performance variable subvariable with a magnitude of $83.50 \%$.

The percentage for the Employee Performance variable (Y) is in the Very Good category. In other words, the respondent believes that the Employee Performance at Telkom Indonesia is good enough but it is important to be further improved in terms of quantity. It can be seen that the highest percentage is in the time sub-variable and the cooperation sub-variable, which is $85.53 \%$ and the lowest value is in the timeliness sub-variable with a magnitude of $82.91 \%$.

\subsection{Testing Measurment Model}

\subsubsection{Validity Test}

By using an error level of $5 \%$ on the $r$ table, we get $r$ table with a value of 0.193 ( $\mathrm{df}=103-2=101)$. It turns out that all items in this research variable are declared valid because all items have a positive correlation.

\subsubsection{Realibility Test}

Based on the results of data processing it is known that the results of the Leadership 3.0 variable reliability test are 0.914 , work motivation is 0.881 and employee performance is 0.849 showing the reliability coefficient values close to 1 so that the statement items in this research variable can be said to be reliable.

\subsection{Analysis of Correlation and Discussion}

Correlation test results as stated in the study indicate whether there is a relationship between Leadership 3.0 with employee performance and Work Motivation with employee performance. Based on the test results prove that there is a positive and significant relationship between Leadership 3.0, Work Motivation with employee performance. This is indicated by the correlation coefficient of Leadership 3.0 with employee performance of 0.666 and the correlation coefficient of Work Motivation with employee performance of 0.571 . Significance value (2-tailed) of $0000<0.05$ indicates that the relationship created between Leadership 3.0 with performance and Work Motivation with performance is significant.

\subsection{Multiple Linear Regression Analysis Test}


Based on Table 2, the constant value (a) is equal to $=9.199$, the regression coefficient for X1 (b1) is 0.322 , and the regression coefficient for X2 (b2) is 0.227 . Thus it can be in the form of multiple linear regression equations as follows:

$$
Y=9,199+0,322 X_{1}+0,227 X_{2}
$$

Table 2. Results of Analysis of Multiple Linear Regression Equations

\section{Coefficients $^{\mathrm{a}}$}

\begin{tabular}{|l|l|r|r|r|r|r|}
\hline \multirow{2}{*}{ Model } & \multicolumn{2}{|c|}{$\begin{array}{c}\text { Unstandardized } \\
\text { Coefficients }\end{array}$} & \multicolumn{2}{c|}{$\begin{array}{c}\text { Standardized } \\
\text { Coefficients }\end{array}$} & \multirow{2}{*}{ Sig. } \\
\cline { 2 - 5 } & \multicolumn{1}{c|}{ B } & Std. Error & Beta & & \\
\hline \multirow{2}{*}{1} & 9.199 & 4.255 & & 2.162 & .033 \\
\cline { 2 - 6 } & $\begin{array}{l}\text { Leadership } \\
3.0\end{array}$ & .322 & .053 & .505 & 6.120 & .000 \\
\cline { 2 - 5 } & $\begin{array}{l}\text { Work } \\
\text { Motivation }\end{array}$ & .227 & .062 & .303 & 3.677 & .000 \\
\hline
\end{tabular}

a. Dependent Variable: Employee Performance

Values a, b1 and b2 in the above equation can be interpreted as follows:

a) $\mathrm{Y}=9,199$ means that if Leadership 3.0 (X1) and work motivation (X2) have a value of 0, then Employee Performance will be worth 9,199 units.

b) X1 = 0.322 means that if Leadership 3.0 (X1) increases by one unit, while work motivation (X2) is constant then Employee Performance will increase by 0.322 units. That way, the better the value of Leadership 3.0, the better the Employee Performance.

c) $\mathrm{X} 2=0.227$ means that if work motivation (X2) increases by one unit, while Leadership 3.0 (X1) is constant then Employee Performance will increase by 0.227 units. That way, the better the value of work motivation, the better the performance of employees.

\subsection{Hypothesis testing}

\subsubsection{Partial Hypothesis Testing (T Test)}

a) Effect of Leadership 3.0 on the performance of employees of Telkom Witel Banten

Based on the results of data analysis, the calculated value of $t$ is 6,120 and $t$ table is 1,660 which means $t$ arithmetic $>t$ table with sig value of 0,000 . The results of the analysis show t count $6,120>\mathrm{t}$ table 1,660 , so it can be stated that Leadership 3.0 affects the performance of employees of Telkom Witel Banten.

b) The influence of work motivation on the performance of employees of Telkom Witel Banten 
Based on the results of data analysis obtained t value of 3,677 and table of 1,660 means that $t$ count $>t$ table with sig value of 0,000 . The results of the analysis show $t$ arithmetic 3,677> t table 1,660, so it can be stated that Work Motivation affects the performance of employees of Telkom Witel Banten.

\subsubsection{Simultaneous Hypothesis Testing (Test F)}

Table 3. Significant Simultaneous Test Results (Test F)

$$
\text { ANOVA }^{\mathrm{a}}
$$

\begin{tabular}{|c|l|r|r|r|c|c|}
\hline \multicolumn{2}{|l|}{ Model } & Sum of Squares & df & Mean Square & F & Sig. \\
\hline \multirow{2}{*}{1} & Regression & 2449.811 & 2 & 1224.906 & 51.949 & $.000^{\mathrm{b}}$ \\
\cline { 2 - 7 } & Residual & 2357.917 & 100 & 23.579 & & \\
\cline { 2 - 8 } & Total & 4807.728 & 102 & & & \\
\hline
\end{tabular}

a. Dependent Variable: Employee performance

b. Predictors: (Constant), Work motivation, Leadership

From the $\mathrm{F}$ test results obtained Fcount of 51,949 with a significance level of 0,000 and $F$ table value of 2.69 , because $F$ arithmetic $(51,949)>F$ table $(2.69)$, because $\mathrm{F}$ arithmetic is greater than $\mathrm{F}$ table then the regression model can be used to predict performance employees or it is said that the Implementation of Leadership 3.0 and Work Motivation together have a simultaneous effect on the Employee Performance of Telkom Witel Banten.

\subsubsection{Determination Coefficient Test $\left(R^{2}\right)$}

Table 3. Coefficient of Determination

Model Summary

\begin{tabular}{|l|r|r|r|r|}
\hline Model & R & R Square & $\begin{array}{c}\text { Adjusted R } \\
\text { Square }\end{array}$ & $\begin{array}{c}\text { Std. Error of } \\
\text { the Estimate }\end{array}$ \\
\hline 1 & $.714^{\mathrm{a}}$ & .510 & .500 & 4.856 \\
\hline
\end{tabular}

a. Predictors: (Constant), Work Motivation, Leadership

This study uses multiple linear regression analysis, so that to determine the coefficient of determination, the value of Adjusted R Square is used. The results of data analysis obtained the Adjusted R Square value of 0.500 or $50 \%$. This shows that Leadership 3.0 and work motivation have a simultaneous effect on employee performance by $50 \%$. Meanwhile, the remaining $50 \%$ is the influence of other variables not examined.

\section{Conclusions and Recommendations}

\subsection{Conclusions}

From the results of data analysis and discussion, it can be concluded: 
1. There is a significant influence between Leadership 3.0 and employee performance. Based on the results of hypothesis testing using the t test where the Ho testing criteria are rejected and $\mathrm{Ha}$ is accepted, it means that there is a significant partial effect of Leadership 3.0 (X1) on employee performance (Y). Correlation analysis test results, the results obtained for the relationship between Leadership 3.0 and employee performance is 0.666 , meaning that there is a strong correlation between Leadership 3.0 and employee performance. This can be a lesson that can be taken especially in the company so that it can be taken into consideration in developing leaders. Companies can develop prospective leaders by implementing the characteristics and characteristics possessed by leaders with Leadership 3.0 style.

2. The results of the analysis between work motivation and employee performance have an influence. Hypothesis testing using the t test where the testing criteria $\mathrm{Ho}$ is rejected and $\mathrm{Ha}$ accepted, shows a partially significant effect of work motivation (X2) on employee performance (Y). Correlation analysis test results, the results obtained for the relationship between work motivation and employee performance is 0.571 , meaning that there is a moderate correlation between work motivation and employee performance.

3. There is an influence for the implementation of Leadership 3.0 and Work Motivation on Employee Performance at Telkom Witel Banten. The results of the F test show that the factors of Leadership 3.0 and work motivation have a significant effect on employee performance at Telkom Witel Banten. Where the magnitude of the influence of 0.51 indicates that Leadership 3.0 and Work Motivation have a simultaneous effect of $51 \%$ on employee performance, while the remaining $49 \%$ is influenced by other factors not observed in this study.

\subsection{Suggestions}

Based on the conclusions above as well as the results of the above research, some things can be suggested as follows:

1. Judging from the results of the calculation of descriptive analysis on the Leadership 3.0 variable, the sub value of the physical aspects variable with the lowest result of $81.49 \%$ which shows the employees of PT Telkom Witel Banten are less satisfied with the leadership style from the physical aspect. This can be improved by asking for feedback every month from the employee, whether the direction from the leader is clear and easy to digest, so that employees understand the goals and objectives of the leader to achieve company goals.

2. Companies need to prepare prospective future leaders by providing training in order to have the nature of Leadership 3.0 and provide motivation to 
subordinates so that employee performance, goals and targets of PT. Telkom Indonesia in Banten Witel can be achieved.

3. Leaders must periodically evaluate and re-socialize targets, as well as the company's vision and mission to employees so that employee motivation is formed and improve employee performance.

4. Judging from the results of the calculation of descriptive analysis on the variable Work Motivation, the sub-value of the variable needs for achievement with the lowest results of $83.5 \%$ which shows the employees of PT Telkom Witel Banten lack of encouragement to excel and the spirit of achievement. Leaders must always provide motivation to employees such as providing training and development to employees. With a good career program and provide rewards to employees if they reach the target to increase the motivation of other employees.

\section{References}

[1] Hasibuan, M. Manajemen Sumber Daya Manusia. Jakarta: PT. Bumi Aksara; 2001.

[2] Ridwansyah, A. Leadership 3.0 : Seni Kepemimpinan Horizontal untuk Semua Orang. Jakarta: PT Gramedia Pustaka Utama; 2013.

[3] Mangkunegara. Manajemen Sumber Daya Manusia Perusahaan. Bandung: Remaja Rosdakarya; 2007.

[4] Rivai , V., \& Mulyadi, D. Kepemimpinan dan Perilaku Organisasi Edisi Ketiga. Jakarta : PT. Rajagrafindo Persada; 2012.

[5] Ambar Teguh Sulistiyani dan Rosidah. Manajemen Sumber Daya Manusia. Yogyakarta: Graha Ilmu; 2003.

[6] Danang, Suntoyo. Manajemen Sumber Daya Manusia. Jakarta: PT Buku Seru. 2012. p. 191 . 